\title{
Introduction to Special Issue
}

The International Politics of Resources: China, Japan and Korea's Demand for Energy, Minerals and Food

Kate Barclay, University of Technology, Sydney

Graeme Smith

University of Sydney

China Japan and Korea's international relations are shaped by the fact that all three are significant importers of resources. This paper proposes two conceptual frameworks for understanding the politics that is taken up in the papers of this Special Issue. The first is to consider the extent to which there is an East Asian model of resource procurement. We find that there are some similarities in the approaches taken by all three countries; for example, their development assistance shares a focus on infrastructure building and a reticence to purposefully influence domestic politics. There are, however, also significant differences due in large part to the individual nature of the states as international actors. The second conceptual framework is the broad contemporary theme of the end of Western dominance of the world order. The main way this affects the international politics of resources in Northeast Asia is through beliefs that the activities of those countries are threatening in some way. In some cases Northeast Asian approaches to resource are seen as a problem because they are not sufficiently liberal, whereas in others the problem is that Northeast Asian powers are seen as replacing Western powers in exploiting resource-rich developing countries.

Keywords: energy security; food security; China threat; development assistance; foreign investment; international relations 


\section{Introduction}

Japan is well known as a resource-poor country, while China has come to be seen as resource-hungry over the last decade or so. South Korea's demand for resources is of a lower order but is nonetheless significant; it is among the world's top importers of energy, and also imports large proportions of the minerals and food it uses. Securing access to resources has been a key driver in Japan's foreign policy since Japan opened up and embarked on the road to modernisation in the late nineteenth century. Following the example of European powers, Japan used colonial and military strategies up until 1945. Since then Japan has used various forms of diplomacy to facilitate its access to energy, minerals and food via international trade, including development assistance and free trade agreements. The government encouraged the private sector to invest in resources production overseas to expand supplies of resources. Japan has also protected its domestic food-producing sector. Korea's strategies for securing resource supplies have centred on diversifying supply as well as using taxes, tariffs and industrial restructuring to reduce vulnerability to world energy markets. Like Japan, Korea protects against the effects of food imports on the rural economy. China has relatively greater domestic supplies of resources, but as its economy has grown so has its reliance on resources from elsewhere. Its efforts to secure supplies of resources from overseas are often portrayed as predatory. China, being a net food exporter, has not intervened in food markets in the same way as Japan and Korea, but its restrictions of exports of rare earths used in global high tech industries show China's willingness to implement trade barriers in some circumstances.

The resources factor is significant in East Asian countries' relations with Africa, Latin America and the Asia Pacific to the point where it may be framed as a security issue; either energy security or food security. This reality raises questions about patterns of development assistance, notably about the extent to which aid diplomacy might be connected to the resource offerings of recipient countries. Japan has been a significant power in world politics for over a century, China is rapidly becoming a major power, and Korea has settled into position as a solid middle power. These are not insignificant international leadership roles, so it is important to consider how the politics of resources in these countries plays out both regionally and globally. 
In bringing together scholars looking at the politics of resources in East Asia, this Special Issue offers a comparative perspective on the similarities and differences between the approaches taken by each country to secure access to crucial energy, mineral and food resources, and the significance of these efforts in terms of international politics. One main question considered by papers in the collection is the extent to which there is an identifiable East Asian approach to resource investment. We do not find a neat "model", suggesting wholesale emulation of first-mover Japan's strategies by Korean and Chinese actors, however, we do find some similarities. These include: 1) assistance to develop infrastructure for resource extraction/production and transport in resource exporting countries; 2) a "win-win" approach overlaying purported altruism in Official Development Assistance (ODA) associated with resources; 3) foreign direct investment (FDI) working in collaboration with ODA to facilitate resource exports from developing countries; and 4) policies attempting to delink ODA from political influence in the recipient country. There are variations, however, in the extent to which the above have been applied by each government, and also big differences in the way different corporations from each of the East Asian countries have conducted their investments in the mining, energy and food sectors. Variations in approach are caused by experiences of individual investors in host countries, and processes shaping the approaches of policymakers in host and investor countries. Despite the similarities noted above, therefore, it is equally accurate to say that the East Asian approach to resource investment is akin to Deng Xiaoping's maxim of "crossing the river while groping for stones".

Another theme explored in this Special Issue is how world historical trends affect the ways in which East Asian resource investment occurs, and understandings of that investment. When East Asian investment in resources is regarded as threatening, the potential for conflict increases, and the rise to prominence of Asian powers immediately upon the end of 500 years of Western hegemony has contributed to the growth of such perceptions. One discourse of the "China threat" may be seen as a reaction by Westerners - used to their own companies and governments being dominant - to the rise of a non-Western power. Another discourse of China threat arises from developing countries, many of which have experienced centuries of domination by the West, being concerned about yet another power exploiting them. 


\section{An East Asian Approach to Resource Investment?}

There are some similarities in the approaches taken by East Asian countries in resource development. Regardless of whether such similarities bear close scrutiny, it is important to note that it is widely perceived that such a model exists, and that it is seen to be different from the "Western" model. ${ }^{1}$ In the 1980s this observation was framed in the concept of the East Asian "developmental state", which was juxtaposed with the Western "regulatory state" (Johnson, 1982). More recently it has been presented as the "Beijing Consensus" (Ramo, 2004; Kennedy, 2010a) rising in opposition to the "Washington Consensus" (Williamson, 1990).

As a starting point in searching for a distinctive East Asian approach, we might venture to suggest that there is a shared emphasis on maintaining a politically neutral stance in overseas resources development: the oft-stated principle of "non interference" in the affairs of the host country. In the 1950s Japan's diplomacy operated under the "Yoshida Doctrine" whereby Japan attempted to stay out of politics and concentrated only on economics as a way to avoid backlash due to its war record (Tarte, 1998). By contrast, Western governments have preferred to be politically interventionist with their development assistance, withholding it (albeit selectively) from governments they have seen as illegitimate. In the post-Cold War world this policy has been called the "Washington Consensus", by which Western governments have used their aid to encourage policy prescriptions they associate with "good governance" in developing countries. During the 1990s Japan was pressured to abandon its reticence to intervene politically and to join the Washington Consensus (Reilly, 2012). Whether or not Ramo (2007) intended it to, ${ }^{2}$ his term "Beijing Consensus" has become shorthand for China's policy of offering development assistance, trade and investment free of political

\footnotetext{
1 "The West" and "Asia" are highly contestable and imprecise terms. We use "the West" here as shorthand for the countries of Europe, North America, Australia and New Zealand. For the purposes of this paper we do not include the former colonies of Latin America in "the West", as they arguably have a different standpoint because of their experiences of having been colonised. "Asia" is used here in a broad sense to include countries east of the Bosphorus River, while "East Asia" means the countries on which this special issue is focused - China, Japan and South Korea.

${ }^{2}$ In a subsequent publication, Brand China, Ramo is a good deal less upbeat, concluding that China is not trusted abroad, its brand is weak, and there is a need for self-invention that is not a "whitewash" (Ramo, 2007).
} 
preconditions, and expecting that each country will follow a distinct path of development. As Shaun Breslin points out, the Beijing Consensus, or the "China model", has come to stand for what China does not represent, rather than what it does. No shock therapy, no inevitable democratisation, no relinquishing of state control, not Western, not neoliberal, not being told what to do by others, nor telling others what to do (Breslin 2011, pp. 1338-1339). Neither Japan nor South Korea is considered to be part of the Beijing Consensus, but all three countries certainly share a distinctively strong respect for the principle of inviolable sovereignty that inclines them in a similar direction.

Several papers in this issue point out that there are limits to the policy of noninterference, and a growing critique, even within China, of whether such an approach is wise. In the wake of the recent decision by the Myanmar regime to bow to popular pressure and suspend construction of the massive Myitsone Dam, Zhu Feng, the deputy director of the Center for International \& Strategic Studies at Peking University noted (Zhu, 2011):

The dam's Chinese investors, for their part, relied too heavily on the depth of the two countries' bilateral ties, and so heavily discounted the project's political risks. Their behaviour also reflects the implied guarantee of official government mercantilism, as well as the complacency of China's state-owned enterprises, which account for most Chinese overseas investment. Operating on the assumption that the government will back them - or bail them out if they fail - they can afford to be cavalier.

The question of whether East Asian strategies are liberal or mercantilist is another influential factor in imaginaries of resource investment. In this debate liberal strategies prefer resources to be accessed through private sector international trade and crossborder investment, and issues of national concern to be negotiated and protected through the mediation of international agencies. By contrast, strategies labelled mercantilist are more state-centric and robust, and tend to reach reflexively towards more direct measures, such as boosting military/naval capacity to defend supplies of resources, government support of trade and investment to secure resource supplies, and non-participation in relevant international regimes. 
Accusations of mercantilism levied at East Asian states often contain the implication that (Western) liberal approaches to securing resources through international agreements and trade are better in terms of international peace and economic growth (Barclay and Epstein, this volume). Chinese, Japanese and Korean actors do, however, generally abide by international regimes (for China see Saul, this volume), and the economies of all three are heavily dependent on world trade. As John Ikenberry (2010) has pointed out, while it is the case that the Western-led nature of world order is currently changing and world order will not be Western-led in future, all the signs are that the liberal nature of the world order is not in decline. He argues that an international system based on open and rules-based cooperation is squarely within the interests of rising Asian powers.

In considering the interests of Northeast Asian governments in this area it is useful to refer to widely accepted definitions of resource security. The United Nations Development Programme Word Energy Assessment defined energy security as "the availability of energy at all times in various forms, in sufficient quantities, and at affordable prices" (UNDP, 2000, p.11). The World Food Summit defined food security as a condition wherein "all people at all times, have physical and economic access to sufficient safe and nutritious food to meet their dietary needs and food preferences for a healthy and active life" (Pinstrup-Andersen, 2009). For both of these definitions security means access. Insofar as world markets and other international regimes provide access, it is then reasonable to assume states will participate. Markets and international cooperation are both subject to failures, however, so it is equally reasonable to expect that states will hedge their bets with government policies to optimise their benefits from markets (Barclay and Epstein, this volume).

The question may then be posed: are East Asian countries "really" being liberal when participating in international regimes, or are they just being instrumentalist in their use of international regimes to secure access to resources? One of the things to note in this line of questioning is the political significance of being understood as "liberal" or not, as China's supposed mercantilism is related to perceptions of the China "threat". Moreover, the distinction implies that real liberal behaviour is motivated by interest in the collective good rather than self-interest. This is a highly questionable proposition, both in terms of liberal understandings of the role of self-interest and in terms of the imputed motivations behind Chinese versus Western actions. 
Another useful alternative to the liberal-mercantilist divide is to look at the problem in terms of a given actor's effectiveness in engaging with international norms and laws, in learning how to play the game to serve their own ends (Kennedy, 2010b). In any case, increased concerns about state intervention in securing resources to an extent reflect historical trends. Cold War imperatives drove concerns about resource security in the 1960s and 1970s, leading to ODA being tightly linked to resource diplomacy, and confining the flow of resources to well-defined political blocs (Buijs and Sievers, 2011). The re-emergence of state engagement in the resources sector in part reflects the end of the belief, prevalent in the globalised and liberalised trading environment of the late 1980s and 1990s, that variously-headquartered multinational companies could obtain access to any resources through markets alone.

Furthermore, while there is state involvement in East Asian resource investment, it does not follow that East Asian states are therefore able to exert their national policies through this investment. Many Chinese resource enterprises are state-owned. Much Japanese overseas resource investment has happened in close affiliation with diplomatic efforts, and its domestic food production is protected (Barclay and Epstein, this volume). Until recently most Korean overseas investment in resources was private, but there has been government structuring of domestic markets to shore up resource security, and recently diplomacy is being used to support overseas investment too. When Chinese resource companies face the choice of national interest or commercial gain, the latter nearly always wins out (Rosen and Hanemann, 2009). Disjuncture between the interests of these companies and their industry lobby groups, and the broader strategic and economic goals of their governments are increasingly apparent (Brant, this volume). Recognising their inability to have direct or effective control over investors (Kim, 2008), Korea has been active in drafting regulations to ensure that proceeds from state-supported overseas investment are repatriated and reinvested.

Recipient countries also have agency in these processes, and may thwart the intentions of investor states. For example, Australia has recently gone against an emerging trend in Asia, by announcing in 2011 that it will no longer accept investorstate dispute settlement (ISDS) provisions in future investment treaties. This marks a break with over two decades of treaty practice, whereby Australia had hitherto consistently obtained ISDS protections in treaties with developing countries with less reliable domestic law protecting foreign investments. Part of Australia's new concern about ISDS is that developed countries may also be subject to arbitration claims brought 
directly by foreign investors, alleging illegal interference with their investments epitomised by a claim brought by a tobacco company in 2011 regarding Australia's plain packaging legislation (Nottage, 2013).

In the short term, Australia's new policy position may not have major repercussions. After all, existing treaties (such as AANZFTA) are not being terminated or renegotiated, so outbound investors in many developing countries in Asia retain ISDS protections. In addition, negotiating partners in bilateral FTAs such as Japan, Korea and China may be prepared to break with their own recent treaty practice and forgo ISDS, in order to secure substantive market access - particularly into Australia's resources sector. In the medium- to long-term, however, Australia's policy shift may impede conclusion of regional treaties such as an expanded Trans Pacific Partnership (TPP). Furthermore, if states in Asia and elsewhere are convinced by the theory and evidence presented by the Australian government for the policy shift, it may also lead to the unravelling of the treaty-based ISDS system that has built up world-wide since the 1960s, generating complex implications for cross-border investment flows (Nottage, this volume).

Differences between the three Northeast Asia countries upon which the articles in this Special Issue focus are visible in the nature of connections between government and industry. The existence of authoritarian government in China does not equate with wellorganised channels for achieving policy through economic actors. Routes for business groups to lobby governments are highly evolved in Japan and Korea, with large conglomerates and industry groups having extensive influence over government ministries, and vice versa (Barclay and Epstein, this volume; Kim, 2008). Most Chinese enterprises, however, have to rely on informal channels to reach policymakers, much as Indian and Brazilian companies do (Deng and Kennedy, 2010). The exceptions to this general rule are the largest state-owned enterprises, such as the three Chinese oil majors, whose heads are routinely rotated out to ministry-level positions (Jiang and Sinton 2011; McCarthy 2013).

Similarities between the approaches of East Asian countries in resource investment lie in conceptualising the provision of ODA in resource exporting countries as an opportunity for both the recipient and the donor; a "win-win" situation. ODA is linked to an expansion of future investment, trade and resource extraction/production, expanding the capacity of the host country to absorb further investment by East Asian companies, achieved through the development of hard infrastructure (such as roads, 
railways, ports and dams) and to a lesser extent in health and education. Interestingly, Reilly (2012) argues that China's adoption of this approach to ODA was shaped by its experiences as a recipient of Japanese aid. In this case, Korea seems to present as an exception, as the Korean government has not had an expansive ODA program (typically around $0.1 \%$ of GNI). South Korean corporations have invested in resources without complementary aid/infrastructure support. However, a massive increase in Korean aid to Africa and North Korea will take place as South Korea has committed itself to the Millennium Development Goals of spending 0.25 per cent of GNI on development assistance by 2015 (Ministry of Foreign Affairs and Trade, n.d.). It will be interesting to see if Korea's aid program will be more like Japan's and China's, with their emphasis on infrastructure and production, or more like Western aid donors, who in recent decades have invested heavily in "governance", or take some other focus.

As well as investment connected to ODA, there is also straight investment in overseas production to increase the overall world supply of the resources in question. Japan has long followed this policy with regard to food supplies (Barclay and Epstein, this volume). The Chinese government counters criticism of Chinese investment in energy production in areas like Sudan by saying it is important to expand overall international supplies of energy.

The preceding paragraphs lay out some broad-brush similarities between the approaches taken by China, Japan and Korea in securing their supplies of energy, minerals and food. There are clearly, however, many important differences. China's vast size, authoritarian polity and its history as a socialist command economy seem to make in an outlier in looking for a common "East Asian" approach to resource development, but the impact of these factors on China's approach to resource development is not straightforward. Japan, Korea and China all initially pursued economic development with the aid of a strong state. Moreover, the Chinese state, while authoritarian and likely to remain so for some time, is not necessarily strong or responsive to the wishes of state-owned companies. Size does not equal strength, Mao's dictum notwithstanding. A recent government white paper entitled China's Peaceful Development (the term "peaceful rise" having been shelved because it could be construed to be threatening) plaintively states, "For China, the most populous developing country, to run itself well is the most important fulfilment of its international 
responsibility." "3 Additionally, while all three countries have more or less combined public and private sector engagements with resource-rich developing countries, they are not unique in this. Indeed, they may be put in the same basket as the European Union, which since decolonisation arguably pursued a policy of mixing government aid with commercial trade to ensure continued access to resources in former colonies in Africa, the Caribbean and the Pacific, under the Yaounde and Lomé Conventions (Grilli, 1996; Lister, 1988; Ravenhill, 1985).

One notable difference between the three countries' approaches is in policies regarding food production and trade. Food production is a qualitatively different kind of economic activity from that of sourcing minerals and energy. Food production is usually carried out by many small actors, and underpins the economies of rural communities. In most countries most food produced domestically is consumed domestically. Mining and energy industries, on the other hand, have huge investment costs so there are relatively fewer actors, and they are mostly export oriented. Most of the inputs (such as investment, equipment, labour and technical expertise) also come from outside, rather than being articulated throughout local communities like agriculture and fishing. Including discussion of food as a resource in with minerals and energy as we have in this Special Issue, enables us to draw comparisons in the international politics of these sectors. Japan and Korea have both implemented trade barriers to protect domestic food production as a way of handling the social instability that arises with income inequality between urban and rural areas with modernisation (Barclay and Epstein, this volume). China has handled the urban-rural divide very differently, allowing a large income inequality to develop. Also, as a net food exporter, China's outlook on food security is also unlike the other two, each of which import well over half of their food supplies. All three, however, share a common historical concern with attempting to maintain food self-sufficiency, particularly in grain.

\footnotetext{
3 “China's Foreign Policies for Pursuing Peaceful Development”, Accessed 6 November 2011 at http://www.gov.cn/english/official/2011-09/06/content_1941354_4.htm.
} 


\section{The End of Western Dominance of the International Order}

One of the defining features of world politics as it is emerging in the twenty-first century is the end of the 500 years of domination by the West over Asia, the start of which was marked by the voyages of Vasco da Gama, Magellan and Columbus, and the era of European colonialism that followed (Bell, 2007). During much of the twentieth century Japan was a world power, and now China and India are assuming that mantle in the twenty-first century, while other non-Western states such as Korea are swelling the ranks of middle powers.

The historical juncture of being at the end of 500 years of world domination by the West is a pertinent lens through which to view the international politics of resources. It is important to note that colonialism did not simply disappear with decolonisation but patterns established by colonial exploitation have continued to be a major influence in the postcolonial world. Legacies of those centuries of Western domination will continue to influence world politics even as Western dominance diminishes. For example, most sources of supply of important energy and mining resources were cornered by Western companies during the period Western powers had dominance. Contemporary Asian investment in energy and mining resources, therefore, is shaped by having to "take what's left", which is mostly in developing countries, and sometimes in countries with records of human rights abuse (Smith, 2012). China and Japan as energy investors have had to establish themselves in a very different environment, for example, in having to deal with state-owned enterprises in independent countries like Saudi Arabia.

A major way in which the rise of Asian powers affects East Asian resource investment is through sensitivities about that investment, especially through opinions that such investment is threatening in some way. A competitive response on the part of Westerners to East Asian states and corporations joining them in world dominance may explain some of the vociferous denunciations of Asian investment by Western commentators. For their part, former colonies' understandings of Asian investors as neo-colonial are also likely to be coloured by the centuries of plain colonialism by European powers and their investors; the increase in Asian investment may seem like replacing one set of exploitative outsiders with another. 


\section{Criticisms of East Asian Resource Investment}

From the 1960s Japanese capital has been invested internationally, with the 1980s marking a spike as Japan's economy rose to be the second largest in the world, in the wake of its excess liquidity problems and the need to offshore production. Since the 1990s the rise of China has eclipsed interest in Japan's demand for resources. These days, the resource issue with which Japan is most commonly associated is overfishing; though concerns about overfishing to meet demand in China are also firmly on the radar. Japan is seen as leading the world now in "guzzling fish", but China, with its massive population eating more protein as it becomes wealthier, is seen as the country to watch for fish imports in the future (Renton, 2005). The concern that China's huge demand for food might lead to global food shortages has been around for a while, with books like Who Will Feed China? Wake-up Call for a Small Planet (Brown, 1995). The discourse around China's overseas resource investment in the English-language media feeds these concerns. For example, China has been described as being on a "relentless mission to capture resources" (McKibbin et al, 2010), spreading "neo-colonial slavery" in developing countries (Callick, 2007) and promoting a development model that is "the most serious challenge that liberal democracy has faced since fascism in the 1930s" (Buruma, 2008).

Japan and China have both been criticised for going against the US- and EU-led international community's avoidance of dealing with "rogue" states (Lee, 2012), as noted earlier in relation to the principle of political non-interference. Considerations about dealing with rogue states may be seen as part of a wider set of questions about the effects on producer countries of trade, investment and development projects in resource sectors. There has been speculation about whether East Asian companies' ways of doing business exacerbate problems of patron-client style governance, causing or contributing to corruption. Japanese trading houses attracted this criticism in the latter half of the twentieth century by working with Southeast Asian governments to secure tropical timber for use in the Japanese construction industry. The investment style led to the development of structures in the logging industries that were ecologically disastrous and damaging to indigenous forest dwellers (Dauvergne, 1997; Tsing, 2005). In the case of China, links have been drawn between Chinese investment strategies and socio-political instability in producer countries. Commentators write of Chinese companies bringing in Chinese labour, or contracting locals under poor conditions, such that great resentment 
builds, erupting in anti-Chinese riots (Windybank, 2005; Hanson, 2009; McKibbin et al, 2010). In recent years riots that have included both some kind of anti-Chinese element and a connection with resource investment have occurred in Tonga, Solomon Islands, and Papua New Guinea (PNG) (Wesley-Smith and Porter, 2010; Smith, 2012). ${ }^{4}$

Chinese-owned mining interests in Zambia are pursuing short-term strategies rather than addressing local environmental and social concerns, and have seen wildcat strikes in response to "precipitous casualization" of the local workforce (Lee, 2009; Haglund, 2009).

While there are no doubt problems with Chinese ODA and private sector investment in resource extraction globally, it seems that some of the representations of wrongdoing on the part of China are overblown, and contain unexamined assumptions of Western investment as superior. Chinese investment in Africa is often denounced as corrupting and exploitative (see, for example, Mbaye, 2011), but Chinese involvement in Africa arguably follows the pattern of the capitalist world system and is very similar to (not worse than) ongoing Western involvement (Sautman and Yan, 2008). Would a Chinese oil company really be any less ethical than a nominally Dutch company, Shell, has been in Nigeria? Similarly, Chinese aid is often assumed to be morally inferior because it is not used to pursue a "governance" agenda, and to be less effective in achieving "development" than Western aid. Empirical analysis of Chinese aid in Africa, however, shows that much Western aid, particularly that focused on governance, has achieved little, while some Chinese infrastructure aid has achieved a great deal (Sautman and Yan, 2008; Bräutigam, 2010). Chinese and Western donors both pursue their own interests and political discourses in Africa, but they use different ideologies and practices of governance to do this (Tan-Mullins, Mohan and Power, 2010). Claims that the "Beijing Consensus" constitutes a purposeful effort on the part of China to encourage autocratic development in opposition to "Western-style" development are also not supported by examination of the range of Chinese diplomatic activities. For example, China's participation in peacekeeping operations in Africa is supportive of transforming war-torn states into liberal democracies (Suzuki, 2009). Each of the pieces

\footnotetext{
${ }^{4}$ In PNG a Chinese state owned enterprise is a new player in the mining scene (see Smith, this volume). In both Solomon Islands and PNG ethnic Chinese business people have been the main buyers for seafood exports (mainly dried sea cucumber, sharks fin, and shells) for over a century, and recent decades Taiwanese and "new" Chinese companies have been key players in fishing for tuna and shark in these countries.
} 
referred to here note a tendency in Western policy analyses to "look for potential threats" in Chinese actions.

\section{Perceptions of Threat on the Part of Westerners}

Some of the representations of East Asian resource investment as being threatening are from Western commentators. There are two main reasons Western commentators may find this investment problematic. One is a philosophical difference, with people believing the East Asian model, as they understand it, is not the "right" way to go about resource interdependence, as outlined in the above discussion about liberalism. Another is a sense of affront on the part of incumbents being challenged by a rising power. These reasons are often mixed together, with the latter being expressed in the discourses of the former. In other words, some allegations of threat from East Asian resource investment are best characterised as attempts to discredit a rising power by questioning the morality of their methods.

The trope of East Asian companies hungry for resources, disregarding of damage to the environment or local people and encouraging bad governance has a long history in Western imaginaries. Judith Bennett (1987, pp. 206-210) has traced historical relations between Chinese settlers and European colonisers in Solomon Islands, showing that negative images of Chinese traders originated as early as the 1800 s with Europeans resentful at the competition offered by Chinese businesses. Bennett found no evidence that the Chinese were any more exploitative of locals than were white colonials.

A sense of rivalry in response to the rise of Japan on the part of Westerners was visible from the late 1970s in a range of books such as Ezra Vogel's (1979) Japan as Number One: Lessons for America, Bill Emmot's (1989) The Sun Also Sets: Why Japan Will Not Be Number One and William Nester's (1990) Japan's Growing Power Over East Asia and the World Economy. Some of this literature expresses rivalry mixed with admiration, while some of it attempts to discredit Japanese success as wrong in various ways. During and after the 1997 Asian crisis, some Westerners triumphantly decried Japanese "crony capitalism" (Milner, 2000). This sense of rivalry carried through into 
Western perceptions of Japanese resource industries, notably fisheries (Barclay, 2007; 2012).

On the other hand, a sense of resentment against newcomer non-Western powers is not the only influence on observations of East Asian resource investment. Western perceptions of Japanese investment, for example, have been coloured by negative associations from Japan's role in World War II. Western understandings of Chinese investment are tinged by the Cold War and China's history of opposition to liberal capitalism, and its continuing authoritarian style of government. Clearly many instances of East Asian resource investment have not been as socially or environmentally responsible as they should have been, just like Western resource investment. And selfinterest plays a role in East Asian countries securing supplies of resources, just as it does in Western countries' approaches to resource supplies. Furthermore, some of the denunciations of Chinese resource investment as mercantilist come, ironically, from the original East Asian mercantilist state, Japan. On this point we would argue that despite Japan's undoubted status as East Asian, it has also had an ambiguous status as Western, due to its early modernisation and industrialisation. In this sense Japan, as an incumbent power responding unfavourably to the rise of new power China, shares the perspective of the West.

The tendency on the part of many Western analysts to find a threat when the evidence is arguably insufficient to justify concern is significant. Insofar as policy is influenced by such ideas they have the potential to unnecessarily build tensions between Western powers and China. It would be much more helpful if Western commentators and policy-makers resigned themselves to the end of Western domination and responded to East Asian investment in resources on its merits - in all its diversity rather than continue to build upon preconceived notions of threat.

\section{Former Colonies' Perceptions of Threat from Asian Investment}

Western commentators accustomed to viewing the rest of the world as subordinate, however, are not the only ones who have found East Asian resource investment to be threatening. Many former colonies of the Western powers also see East Asian resource investment as threatening. With the dismantling of formal militarily controlled colonies 
in the second half of the twentieth century anti-colonial activists found that continued imperial domination went on through the influence of corporations from former colonising states in the economies of former colonies. This process, involving entwined processes of cultural assimilation, asymmetrical economic interdependence and sociopolitical influence, has been called neo-colonialism. The liberal pillars of global capitalism, trade liberalisation and associated political changes pushed by aid donors and international financial institutions such as the World Bank, are some of the main conduits by which neo-colonialism is believed to occur. While the term was first applied to former European colonial powers, East Asian investment has also been described as neo-colonial.

In Africa, fears of Chinese interests using their powerful position in developing countries to unfairly pursue their own interests at the expense of the host countries are complicated by China's history of anti-colonial activity in Africa dating from the 1950s. Some African elites actively promote this history of cooperation as part of their technique for defending and building support for contemporary Chinese investment (Large, 2008). In the islands of the Pacific, however, China has no such history of anticolonial cooperation, and consequently is more straightforwardly seen as potentially neo-colonial (Smith, 2012).

China's strong commitment to the principle of political non-intervention in some cases means it is thought to make it less colonial than Western countries. Former colonial powers have been willing to use their economic power over aid recipients to intervene in their domestic politics in the name of improving "governance". Former colonies are understandably sensitive about their sovereignty and thus appreciate this less domineering aspect of Chinese involvement (Moyo, 2009).

The remedies for ameliorating sensitivities about a threat from China thus differ depending on whether one is dealing with former colonies or Western powers. Western countries usually want China to adhere to liberal norms - placing trust in world trade to provide supplies of necessary resources and participating in regimes that support the international trade in resources - to make China less threatening. China's "charm offensive" deployed as a soft-power tool to allay fears of a "China threat" in the West has involved demonstrating its liberal credentials (Suzuki, 2009). Demonstrating liberal 
credentials, however, will not avert the fears held by former colonises that China might be a latent neo-colonialist. Indeed, open participation in world markets and adherence to the norms of international regimes are keys to the operation of neo-colonialism, so China being more liberal will in no way reduce the likelihood of it being neo-colonial. China needs quite a different charm offensive to allay fears of a China threat in former colonies. The history of Chinese South-South cooperation is a good background for this charm offensive but as China is increasingly viewed as a powerful and wealthy country it needs new ways to demonstrate that it will not dominate smaller countries. One difficulty with this is that the two charm offensives tend to counteract each other. As seen above in the debates over China's political non-interference in resource producing countries, efforts not to dominate politically in developing countries may result in increased perceptions of threat on the part of Western powers. That is, Western powers want China to influence the politics of resource-producing countries in alignment with the good governance agenda, so it will be difficult for China to satisfy those demands while simultaneously demonstrating to resource producing countries that it is not.

Interestingly, Korea has not been considered a threat in the way Japan was in the 1980s and China is now. This difference has not come about because Korean resource investment has been any more ethical or in tune with local norms than that of the other two. For example, in 2008 Daewoo Logistics did a deal with the government of Madagascar for a 99-year lease for 3.2 million hectares of land - half the arable land in the whole country - for the purpose of growing corn and palm oil. Existing public dissatisfaction with the Madagascar government of the day was fuelled by outrage over this deal, resulting in a coup d'état. The new government cancelled the deal with Daewoo (Oviedo, 2011). For explanations of why a Korea "threat" thesis has not gained traction, we look rather to broader political and historical factors: for instance, the fact that it is a middle power and thus not seen as potentially dominating other countries in the same way as larger powers Japan and China. Furthermore, Korea does not have Japan's history of imperial expansion, nor, until recently, has the Korean state been obviously connected to the overseas resource investments of Korean chaebol. So the actions of Korean corporations have not been seen as the actions of "Korea" in the same way as the actions of state-owned Chinese oil companies may be seen as actions of "China", for example. 


\section{Conclusion}

In this Special Issue the substantive contributions consider a series of questions that are foreshadowed in this introductory paper. First, some of the papers examine the question of how East Asian governments and companies actually behave in resource-producing developing countries? James Reilly traces the history of patterns of development assistance in relation to resource investment, which were first employed by Japan, and are now employed by China. He studies the international political consequences of competitive aid and resource investment between China and Japan in Myanmar. The paper by Philippa Brant takes scholarship on Chinese aid and resource investment in Africa and looks at whether Chinese aid and resource investment in Pacific Island countries is following similar trajectories. Specifically, how directly connected is Chinese foreign policy and resource investment? Is it accurate to speak of private sector investment being part of a state-led form of resource diplomacy? Graeme Smith then looks at Chinese involvement in mining in Papua New Guinea and employment patterns. How do the labour strategies vary from those in Western mining investment, and what are the consequences for Papua New Guinean society and the employees involved?

A second major set of questions addressed by the papers in this Special Issue is how East Asian governments treat the role of markets and international regimes in resource interdependence. Ben Saul's paper asks how China measures up in terms of abiding by international law. Kate Barclay and Charlotte Epstein explore the Japanese government's balancing act between world markets and government support for domestic producers in policies for food security, and Japan's positioning in international organisations to promote these policies. Ming Hwa Ting and John Seaman look at how the unfolding of markets in rare earth minerals has led to the situation where China has a virtual monopoly on supply. The Chinese government has at times restricted exports for political motives, and the fallout from this is may affect territorial politics as Japan and South Korea, both heavily dependent on rare earths for their high technology industries, look to secure claims over seabed areas with potential for rare earth mining. Given that East Asian governments and companies are not the only drivers in the production of and trade in resources, what are some of the other influential factors? Luke Nottage's paper shows how an Australian policy about protection of international 
investor interests may affect the general environment of cross border investment in resources in the Asia Pacific region.

The international politics of resources in East Asia have become increasingly important in recent years as the world economy has come to rely heavily on development in Asia to cover for the stagnation going on in Europe and the USA. Resources are the raw ingredients of economic growth in those economies, at least as they are currently structured, so this topic will be of major significance for the foreseeable future.

\section{Acknowledgements}

Many thanks to the University of Technology Sydney China Research Centre and the University of Sydney China Studies Centre for sponsoring the workshop at which this collection of papers was first presented. Thanks are due to all workshop participants for their comments on the papers, with special thanks to Prof Steve Fitzgerald, Prof Peter Drysdale and Prof Michael Wesley for helping develop conceptual frameworks for the workshop. Thanks also to two anonymous reviewers for this paper, whose comments helped us refine our arguments.

\section{References}

Barclay, Kate (2007) Fishing. Western, Japanese and Islander Perceptions of Ecology and Modernization in the Pacific. Asia Pacific Journal: Japan Focus. Available at http://www.japanfocus.org/-Kate-Barclay/2508, accessed 20 August 2010.

Barclay, Kate (2012) Development and Negative Constructions of Ethnic Identity: Responses to Asian Fisheries Investment in the Pacific. The Contemporary Pacific 24(1), pp. 33-63.

Bell, C. (2007) The End of the Vasco da Gama Era: The Next Landscape of World Politics. (Sydney: Lowy Institute for International Policy). 
Bennett, J. (1987) Wealth of the Solomons: A History of a Pacific Archipelago, 18001978. Pacific Islands Monograph Series no. 3 (Honolulu: University of Hawai'i Press).

Bräutigam, Deborah A. (2010) The Dragon's Gift: The Real Story of China in Africa. (Oxford: Oxford University Press).

Breslin, Shaun (2011) The 'China model' and the global crisis: from Freidrich List to a Chinese mode of governance? International Affairs 87(6), pp. 1323-1343.

Buijs, B. and H. Sievers (2011) Critical Thinking about Critical Minerals. CIEP-BGR Briefing Paper. Available at http://www.clingendael.nl/publications/2011/20111111_ciep_bgr_briefingpaper _buijs_sievers_critical_thinking_about_critical_minerals.pdf, accessed 11 December 2011.

Brown, Lester R. (1995) Who Will Feed China? Wake-up Call for a Small Planet (Washington DC: Worldwatch Institute).

Buruma, Ian (2008) China's dark triumph: The success of its economy poses a serious challenge to liberal democracy. Los Angeles Times. 13 January.

Callick, Rowan (2007) China's neo-colonial slavery in PNG. The Australian. 12 February. Available at http://www.theaustralian.com.au/business/chinas-neocolonial-slavery-in-png/story-e6frg8zx-1111112977807, last accessed 28 February 2013.

Dauvergne, P. (1997) Shadows in the Forest: Japan and the Politics of Timber in Southeast Asia (Cambridge MA: MIT Press).

Deng, G. and S. Kennedy (2010) Big Business and Industry Association Lobbying in China: The Paradox of Contrasting Styles. The China Journal 63, pp. 101-25.

Emmot, Bill (1989) The Sun Also Sets: Why Japan Will Not Be Number One (London: Simon \& Schuster). 
Grilli, E. R. (1996) The European Community and the Developing Countries (Cambridge UK: Cambridge University Press).

Haglund, Dan (2009) In it for the Long Term? Governance and Learning Among Chinese Investors in Zambia's Copper Sector. The China Quarterly 199, pp. 627-646.

Hanson, Fergus (2009) China: Stumbling Through the Pacific. (Sydney: Lowy Institute for International Policy).

Ikenberry, John G. (2010) The Liberal International Order and its Discontents. Millennium: Journal of International Studies, 38(3), pp. 509-521.

Jiang, Julie and Jonathan Sinton (2011) Overseas Investments by Chinese National Oil Companies. IEA. Available online at http://www.iea.org/publications/freepublications/publication/name,3947,en.html , last accessed 28 February 2013.

Johnson, Chalmers (1982). MITI and the Japanese Miracle (Stanford, CA: Stanford University Press).

Kennedy, Scott (2010a) The Myth of the Beijing Consensus. Journal of Contemporary China 19(6), pp. 461-77.

Kennedy, Scott (2010b) The Mandarin Learning Curve: How China Is Reshaping Global Governance. In China Social Science Workshop (Stanford, CA: Stanford University).

Kim, Joongi (2008) A Forensic Study of Daewoo's Corporate Governance: Does Responsibility for the Meltdown Solely Lie with the Chaebol and Korea? Northwestern Journal of International Law \& Business 28(2), pp. 273-340.

Large, Daniel (2008) Beyond 'Dragon in the Bush': The Study of China-Africa Relations. African Affairs 107, pp. 45-61. 
Lee, Chin Kwan (2009) Raw Encounters: Chinese Managers, African Workers and the Politics of Casualization in Africa's Chinese Enclaves. The China Quarterly 199, pp. 647-666.

Lee, John (2012) China's Geostrategic Search for Oil. Washington Quarterly 35(3), pp. 75-92.

Lister, M. (1988) The European Community and the Developing World: the Role of the Lome Convention (Aldershot: Avebury).

Mbaye, Sanou. 2011. Africa will not put up with a colonialist China. The Guardian. Available online at http://www.guardian.co.uk/commentisfree/2011/feb/07/china-exploitationafrica-industry/print, last accessed 28 February 2013.

McCarthy, Joe (2013) Crude Oil-Mercantilism? Chinese Oil-Engagement in Kazakhstan. Pacific Affairs. 85(3), forthcoming.

McKibbin, W., M. Cook, M. Fullilove, M. Wesley, A. Bubalo, R. Medcalf, F. Hanson, J. Hayward-Jones, S. Roggeveen (2010) How the Roar of China's Tiger Will Be Heard Across the World. The Australian, 13 February, Inquirer p.2.

Milner, A. (2000) What happened to "Asian Values"? in G. Segal and D.S.G. Goodman (eds.) Towards Recovery in Pacific Asia (London: Routledge), pp. 56-68.

Ministry of Foreign Affairs and Trade, Republic of Korea (no date) Korea's ODA at a Glance. Available at http://www.odakorea.go.kr/eng/include/glance.php, accessed 7 December 2011.

Moyo, Dambisa (2009) Dead Aid: Why aid is not working and how there is a better way for Africa (London: Allen Lane).

Nester, William (1990) Japan's Growing Power Over East Asia and the World Economy (New York: St Martin's Press).

Nottage, Luke (2013) Investor-State Arbitration Policy and Practice after Philip Morris 
Asia v Australia, in Leon Trakman and Nicola Ranieri (eds.) Regionalism in International Investment Law (Oxford: Oxford University Press, 2013), pp. 45274.

Oviedo, Sheila (2011) Avoiding the Land Grab: Responsible Farming Investment in Developing Nations (Amsterdam: Sustainanalytics). Available at http://www.sustainalytics.com, accessed 8 December 2011.

Pinstrup-Andersen, Per (2009) Food Security: Definition and Measurement. Food Security 1, pp. 5-7.

Ramo, Joshua Cooper (2004) The Beijing Consensus: Notes on the New Physics of Chinese Power (London: The Foreign Policy Centre). Available at http://www.fpc.org.uk/fsblob/244.pdf, accessed 6 November 2011.

Ramo, Joshua Cooper (2007) Brand China. (London: The Foreign Policy Centre). Available at http://fpc.org.uk/fsblob/827.pdf, accessed 28 February 2013.

Ravenhill, John (1985) Collective Clientalism: The Lome Conventions and North-South Relations (New York: Columbia University Press).

Reilly, James (2012) A Northeast Asian Model of ODA? Comparing Chinese, Japanese and Korean Official Development Assistance, in Joern Dorsch and Christopher Dent (eds.), The Asia-Pacific, Regionalism and the Global System (London: Edward Elgar).

Renton, Alex (2005) One in Ten Fish is Eaten in Japan. So Why Don't They Know There's a Shortage? Observer Food Monthly, Sunday 10 April. Available http://www.guardian.co.uk, accessed 19 August 2010.

Rosen, Daniel H. and Thilo Hanemann (2009) China's Changing Outbound Foreign Direct Investment Profile: Drivers and Policy Implications (Washington DC: Peterson Institute for International Economics).

Sautman, B. and Yan H. (2008) The Forest for the Trees: Trade, Investment and the China-in-Africa Discourse. Pacific Affairs, 81(1), pp. 9-29. 
Smith, Graeme (2012) Chinese Reactions to Anti-Asian Riots in the Pacific. Journal of Pacific History 47(1), pp. 93-109.

Suzuki Shogo (2009) Chinese Soft Power, Insecurity Studies, Myopia and Fantasy. Third World Quarterly, 30(4), pp. 779-793.

Tan-Mullins, May, Giles Mohan and Marcus Power (2010) Redefining “Aid” in the China-Africa Context. Development and Change, 41(5), pp. 857-881.

Tarte, S. (1998) Japan's Aid Diplomacy and the Pacific Islands (Canberra, Australia: Asia Pacific Press).

Tsing, Anna Lowenhaupt (2005) Friction: An Ethnography of Global Connection. (Princeton and Oxford: Princeton University Press).

UNDP (2000) World Energy Assessment: Energy and the Challenge of Sustainability. (New York: United Nations Development Programme [UNDP]; United Nations Department of Economic and Social Affairs; World Energy Council).

Vogel, Ezra (1979) Japan as Number One: Lessons for America. (Cambridge Mass: Harvard University Press).

Wesley-Smith, Terence and Edgar A. Porter (2010) China in Oceania: Reshaping the Pacific? (New York: Berghahn Books).

Williamson, John (1990) What Washington Means by Policy Reform, in John Williamson (ed.), Latin American Adjustment: How Much Has Happened? (Washington DC: Institute for International Economics).

Windybank, Susan (2005) The China Syndrome. Policy 21(2), pp. 1-6. Available online at http://www.cis.org.au/images/stories/policy-magazine/2005-winter/2005-212-susan-windybank.pdf, last accessed 28 February 2013. 
Zhu Feng (2011) The Limits of Power: Why China Is a "Bad Neighbour". Available at http:// www.firstpost.com/world/the-limits-of-power-why-china-is-a-badneighbour-120299.html, accessed on 6 November 2011. 